\title{
The effects of discourse force on the comprehension of fables, parables, and folktales
}

\author{
TONY M. DUBITSKY, RICHARD J. HARRIS, LINDA K. SANDERS, \\ ROBERT J. BETZEN, and ROBIN L. BUNTON \\ Kansas State University, Manhattan, Kansas 66506
}

\begin{abstract}
The experiment examined the effects of discourse force (whether the function of a passage is to entertain, provide literary-aesthetic pleasure, instruct, or inform) on memory and comprehension for information from fables, folktales, and parables. Discourse force was manipulated while the passage content was held constant. Results showed that discourse force affected some evaluative judgments about a passage but had no effects on memory.
\end{abstract}

In a recent theoretical paper, Brewer (1980) extended the linguistic construct of speech-act force to the domain of discourse. Just as a sentence can possess an illocutionary force, so can a text. For example, a fable by Aesop may on one level persuade the reader to adopt virtuous behavior or on another level merely entertain the reader. These two different illocutionary forces of the text are the discourse forces.

Discourse force is a psychological concept, being the author's intention or motivation in writing the text. Whether or not this intention produces the desired effect in the reader is an empirical question. In Brewer's (1980) system, there are four primary discourse forces: A text can be written primarily to persuade, to inform, to entertain, or to offer literary-aesthetic pleasure. For example, a newspaper story may largely inform, a mystery novel may entertain, a fable may persuade, and a poem may provide literary-aesthetic pleasure.

Although there have been few studies of discourse force to date, there have been numerous studies on memory and comprehension of the speech-act forces of sentences (e.g., Clark, 1978, 1979; Clark \& Lucy, 1975; Gibbs, 1979, 1981; Jarvella \& Collas, 1974; Kemper, 1980). These studies have examined the processing of sentences that are ambiguous with respect to "direct" and "indirect" meanings from different illocutionary forces. For example, depending upon the context, the sentence "it's hot in here" could be either an "indirect" request to open the window or a "direct" assertion. Sentences may thus possess multiple illocutionary forces, some of which may be made more salient than others, depending upon the context in which the sentence is uttered.

This research was supported by a grant from the Kansas State University Bureau of General Research to the second author. Requests for reprints may be sent to Richard J. Harris, Department of Psychology, Kansas State University, Manhattan, Kansas 66506.
The present study examined the effects of discourse force on the comprehension of fables, folktales, and parables, since passages of this genre could be interpreted as possessing multiple discourse forces. Discourse force was varied using a contextual manipulation similar to the one in the previously mentioned sentencememory studies. This contextual manipulation was used to induce a mental set in the subject, thus enhancing one particular discourse force, while the passage remained the same across discourse-force conditions. Thus, discourse force varied, but the text was held constant. Subjects were required to rate each passage on several affective scale dimensions and then evaluate the truth value of memory test statements based on passage content. Time of test was also varied to determine whether discourse force differentially influenced short-term and long-term memory. Subjects responded to memory test statements either immediately after reading the passage or after reading all passages.

\section{METHOD}

\section{Subjects}

Ninety-two students in introductory psychology classes served as subjects in order to fulfill course requirements. They were tested in groups.

\section{Materials}

The passages used were the Jewish folktales "The Golden Shoes" and "It Could Always Be Worse" (both from Ausubel, 1948), "The Parable of the Good Samaritan" (adapted from the Good News Bible, 1976, Luke 10:30-35), the fable "The Dog and His Shadow" (Rumelhart, 1977), and the Persian folktale "The Food of the Cloak" (Shah, 1972).

Four "context-force" paragraphs were written for each of the five passages. Following from Brewer (1980), these contextforce paragraphs emphasized the informative, entertaining, literary aesthetic, and didactic discourse forces. We thought a more appropriate label in this case for Brewer's persuasive discourse force would be "didactic," since the materials we used exhorted the reader to follow a righteous path by teaching a moral lesson. Sample context-force paragraphs and the corresponding passage are shown in Table 1 . 
Table 1

Sample Materials

\section{SAMPLE TARGET PASSAGE}

\section{"It Could Always Be Worse"}

(from Ausubel, 1948)

The poor Jew had come to the end of his rope. So he went to his rabbi for advice.

"Holy Rabbi!" he cried. "Things are in a bad way with me, and are getting worse all the time! We are poor, so poor, that my wife, my six children, my in-laws and I have to live in a oneroom hut. We get in each other's way all the time. Our nerves are frayed and, because we have plenty of troubles, we quarrel. Believe me-my home is a hell and I'd sooner die than continue living this way!"

The rabbi pondered the matter gravely. "My son," he said, "promise to do as I tell you and your condition will improve."

"I promise, Rabbi," answered the troubled man, "I'11 do anything you say."

"Tell me-what animals do you own?"

"I have a cow, a goat and some chickens."

"Very well! Go home now and take all these animals into your house to live with you."

The poor man was dumbfounded, but since he had promised the rabbi, he went home and brought all the animals into his house.

The following day the poor man returned to the rabbi and cried, "Rabbi, what misfortune have you brought upon me! I did as you told me and brought the animals into the house. And now what have I got? Things are worse than ever! My life is a perfect hell-the house is turned into a barn! Save me, Rabbihelp me!"

"My son," replied the rabbi serenely, "go home and take the chickens out of your house. God will help you!"

So the poor man went home and took the chickens out of his house. But it was not long before he again came running to the rabbi.

"Holy Rabbi!" he wailed. "Help me, save me!" The goat is smashing everything in the house-she's turning my life into a nightmare."

"Go home," said the rabbi gently, "and take the goat out of the house. God will help you!"

The poor man returned to his house and removed the goat. But it wasn't long before he again came running to the rabbi, lamenting loudly, "What a misfortune you've brought upon my head, Rabbi! The cow has turned my house into a stable! How can you expect a human being to live side by side with an animal?"

"You're right-a hundred times right!" agreed the rabbi. "Go straight home and take the cow out of your house!"

And the poor unfortunate hastened home and took the cow out of his house.

Not a day had passed before he came running again to the rabbi. "Rabbi!" cried the poor man, his face beaming. "You've made life sweet again for me. With all the animals out, the house is so quiet, so roomy, and so clean! What a pleasure!"

\section{CONTEXT PARAGRAPHS FOR DISCOURSE FORCES}

\section{A. Informative Discouse-Force Paragraph}

The following folktale portrays small-town shtetl (Eastern European Jewish ghetto) life in the late 19th and early 20th centuries. In the shtetl, daily survival was a struggle. Most of the inhabitants lived in terrible poverty. Jewish persecution from outside the shtetl was very common. Traveling gangs or pogroms would often stage surprise attacks, destroying fields of meager crops, burning huts, and beating up townspeople. While religion offered shtetl inhabitants much consolation, the rabbis (teachers and spiritual leaders) often engaged in religious debates which were of no practical use to anybody. Read this Jewish folktale of a clever rabbi whose seemingly impractical logic enables a fellow villager to cope with poverty.

\section{B. Entertaining Discourse-Force Paragraph}

The folktale you are about to read is in the same tradition as the popular play and film Fiddler on the Roof. In this folktale of Eastern European Jewish ghetto (shtetl) life, a rabbi (teacher and spiritual leader) gives absurd advice to a poor farmer. Although the rabbi's advice finally works, this story is nevertheless a comment on the topsy-turvy reasoning of ten used by rabbis who were debating such matters as the number of angels that could fit on the head of a pin. The poor farmer not only fails to see the logic of the rabbi's absurd advice but even thinks that the rabbi has done him a tremendous favor at the end of the tale when indeed nothing has changed. Read this Jewish folktale of comic inspiration now.

\section{Literary-Aesthetic Discourse-Force Paragraph}

Contrast and repetition are two of the most important elements in this folktale of shtetl (Eastern European Jewish ghetto) life in the late 19 th and early 20 th centuries. The following tale portrays the village rabbi (teacher and spiritual leader) as a wise, calm, self-assured man, while the poor farmer who seeks his help is nervous, upset, and uncertain. The advice coming from this seemingly wise rabbi is, at first thought, pure nonsense. This is yet another irony. We don't expect such foolish advice from such a scholarly man, yet the advice really does work out so we are doubly fooled.

Repetition is also important as there are five meetings between the rabbi and the farmer. Each time (until the end of the tale) that the farmer appears before the rabbi he is more distraught and desperate for the rabbi's help. In contrast, the rabbi is always self-confident and self-assured each time he meets with the farmer. Read this classic Jewish folktale now.

\section{Didactic Discourse-Force Paragraph}

One human shortcoming is to magnify our own misfortunes and troubles, failing to appreciate that matters could be worse and complaining that they should be better. It is like realizing the grass may be greener on the other side without being thankful for having a yard. Yes-it could be worse-you might not even have a lawn. So be thankful for what you have. The following folktale persuades us to view our troubles relativistically, and in so doing, feel less burdened by them. As one writer has put it, "by viewing from the perspective of the totality of all troubles, it loses some of its alarming character." Read this Jewish folktale of a clever rabbi (teacher and spiritual leader) who enables a fellow villager to view life more optimistically.

\section{MEMORY TEST STATEMENTS} nate)

The poor Jew worked part time as a dairyman. (Indetermi-

The poor Jew visited the rabbi for spiritual advice. (False)

The man lived in a one-room hut with his wife, six children, and in-laws. (True) ion)

The poor man had great confidence in the rabbi. (Implica-

The man's poor living conditions had caused many family squabbles. (Implication)

The rabbi's first recommendation was to have the man get rid of his farm animals. (False)

The goat smashed everything in the man's house. (True)

The poor man gave the rabbi some home-made chicken soup as a token of appreciation. (Indeterminate) 
Occurrences of context-force paragraphs with passages were completely counterbalanced, resulting in five different sets of five context-force paragraph-passage pairs. Each of the five sets was administered to subjects in the form of a stapled booklet containing typed materials for each one of the five passages in the following order: context-force paragraph, passage, rating scales, and memory test statements. The one exception was in the no-context condition, in which no context-force paragraph occurred.

\section{Design}

In a 5 by 2 factorial design, context force (informative, entertaining, didactic, literary-aesthetic, or no context) served as a within-subjects factor, and time of memory test (immediate or delayed) served as a between-subjects factor. The latter factor was included in order to determine whether discourseforce effects occurred differently in short-term and long-term memory.

\section{Procedure}

Immediate group. After having been told about the general nature of the experimental task and the subsequent memory test, subjects read a practice passage ("The Smuggler," from Shah, 1972), rated it on the affective scales described below, and responded to memory test statements.

Next, subjects were given the booklets of experimental materials. Each passage was rated on the following 5-point scales: informativeness $(1=$ not very informative, $5=$ very informative $)$, entertainingness $(1=$ not at all entertaining, $5=$ very entertaining), persuasiveness $(1=$ not at all persuasive, $5=$ very persuasive), literary appeal ( $1=$ not very good literature, $5=$ very good literature), interest $(1=$ not very interesting, $5=$ very interesting $)$, comprehensibility $(1=$ very easy, $5=$ very difficult $)$, imageability $(1=$ difficult to visualize, $5=$ easy to visualize $)$, and humor ( $1=$ not at all humorous, $5=$ humorous $)$.

Finally, subjects responded to eight statements (two true, two false, two indeterminate, and two implied true statements) based on information in the preceding passage, rating each one on a scale ranging from 1 (definitely false) to 5 (definitely true). Sample statements of each type are shown in Table 1. This entire sequence of reading the passage, rating it on the scales, and responding to the memory test statements was repeated for each of the five passages. Subjects worked at their own pace, usually completing the entire task in about $30 \mathrm{~min}$.

Delayed group. The procedure was the same for the delayed group as that for the immediate group, except that all memory test statements were completed after all the passages had been read and rated.

\section{RESULTS AND DISCUSSION}

Missing truth-value judgments were replaced by the mean of the other responses to the same memory statement type across passages by the same subject, with the same procedure followed when subjects erroneously gave two responses to one test statement. Due to failure to understand instructions for the memory task, data from four subjects were deleted. Thus, 92 subjects contributed ratings, but only 88 responded to the memory task.

The mean ratings are shown in Table 2. Nine separate one-way analyses of variance were performed on the responses to each of the rating scales collapsed over passages. Results showed a significant effect on the informativeness ratings $[\mathrm{F}(4,364)=2.73, \mathrm{MSe}=.95$, $\mathrm{p}<.03$ ]. Although a Newman-Keuls multiplecomparisons test showed no significant differences among the means, this may be due to the lesser power of post hoc tests in general, relative to omnibus-F tests. Nevertheless, there was a trend for the entertaining and no-context passages to be rated less informative than the other three types. Second, there was a significant effect on the interest ratings $[\mathrm{F}(4,364)=2.42, \mathrm{MSe}=$ $.94, \mathrm{p}<.05]$, with the informative-context passages rated significantly more interesting than the other passages ( $p<.05$, Newman-Keuls test), among which

Table 2

\begin{tabular}{|c|c|c|c|c|c|c|}
\hline & No Context & Informative & Didactic & Entertaining & Literary & Mean \\
\hline \multicolumn{7}{|c|}{ Mean Ratings $(1=$ Low, $5=$ High $)$} \\
\hline Informa tiveness & 3.33 & 3.60 & 3.66 & 3.28 & 3.53 & 3.48 \\
\hline Imageability & 4.43 & 4.33 & 4.24 & 4.38 & 4.56 & 4.39 \\
\hline Understanding & 1.89 & 2.01 & 1.96 & 1.88 & 1.94 & 1.93 \\
\hline Persuasiveness & 2.96 & 3.02 & 3.35 & 3.17 & 3.17 & 3.13 \\
\hline Humorousness & 2.97 & 3.09 & 2.89 & 3.23 & 3.12 & 3.06 \\
\hline Entertainingness & 3.54 & 3.77 & 3.66 & 3.67 & 3.77 & 3.68 \\
\hline Interest & 3.46 & 3.86 & 3.59 & 3.66 & 3.77 & 3.67 \\
\hline Literariness & 3.50 & 3.61 & 3.58 & 3.64 & 3.58 & 3.58 \\
\hline \multicolumn{7}{|c|}{ Mean Truth-Value Responses ( $1=$ False, $5=$ True $)$} \\
\hline \multicolumn{7}{|l|}{ Immediate Test } \\
\hline True & 4.49 & 4.44 & 4.63 & 4.56 & 4.64 & 4.55 \\
\hline False & 1.62 & 1.92 & 1.50 & 1.72 & 1.61 & 1.68 \\
\hline Implied & 3.38 & 3.57 & 3.48 & 3.49 & 3.74 & 3.62 \\
\hline Indeterminate & 2.84 & 2.66 & 2.66 & 2.78 & 2.72 & 2.73 \\
\hline \multicolumn{7}{|l|}{ Delayed Test } \\
\hline True & 4.26 & 4.48 & 4.27 & 4.43 & 4.26 & 4.34 \\
\hline False & 1.70 & 1.55 & 1.77 & 1.86 & 1.55 & 1.69 \\
\hline Implied & 3.55 & 3.70 & 3.50 & 3.69 & 3.33 & 3.55 \\
\hline Indeterminate & 2.73 & 2.64 & 2.75 & 2.74 & 2.75 & 2.72 \\
\hline
\end{tabular}


there were no significant differences. There were no significant effects of context force on the other scale dimensions. One possible, although speculative, reason is that variation across passages (they differed widely in content, tone, style, and length) "washed out" any global effects of context force.

Results from the memory task also appear in Table 2 and were analyzed by four separate 2 by 5 analyses of variance, with independent variables of time of test (immediate or delayed) and context force (no context, informative, entertaining, didactic, or literary-aesthetic). Separate analyses were performed for true, false, implied, and indeterminate test items.

For the analysis of the true memory test statements, there was a marginal main effect of delay $[F(1,86)=$ $3.78, \mathrm{MSe}=1.27, \mathrm{p}=.055]$, with true test statements being rated true more often in the immediate than in the delayed memory condition. In neither this analysis nor any of the other three were any other main effects or interactions significant at the .05 level. This failure to obtain context-force effects using the memory task suggests that either the contextual manipulation of discourse force was not potent enough or that the truth-value ratings did not reflect subtle modifications in information processing. ${ }^{1}$

Results from the rating data in this experiment have shown that it is possible to influence judgments about a passage by varying discourse force. For the majority of the scales, passages with no preceding context-force paragraph received lower ratings than those preceded by any of the contexts. The contexts may have served as "given" information, "priming" the subjects to integrate the "new" information in the subsequent passage with this given information. In conclusion, we believe that we have found a promising way to study discourse processing by holding the passage content constant and varying discourse force.

\section{REFERENCES}

Ausubel, N. Treasury of Jewish folklore. New York: Crown, 1948.

BrEWER, W. F. Literary theory, rhetoric, stylistics: Implications for psychology. In R. J. Spiro, B. C. Bruce, \& W. F. Brewer (Eds.), Theoretical issues in reading comprehension: Perspectives from cognitive psychology, linguistics, artificial intelligence, and education. Hillsdale, N.J: Erlbaum, 1980.

Clark, H. H. Inferring what is meant. In W. J. M. Levelt \& G. B. Flores d'Arcais (Eds.), Studies in the perception of language. London: Wiley, 1978.

Clark, H. H. Responding to indirect speech acts. Cognitive Psychology, 1979, 11, 430-477.

Clark, H. H., \& LucY, P. Understanding what is meant from what is said: A study in conversationally conveyed requests. Journal of Verbal Learning and Verbal Behavior, 1975, 14, 56-72.

Gibss, R. W. Contextual effects in understanding indirect requests. Discourse Processes, 1979, 2, 1-10.

Gibss, R. W. Your wish is my command: Convention and context in interpreting indirect requests. Journal of Verbal Learning and Verbal Behavior, 1981, 20, 431-444.

Good News Bible. New York: American Bible Society, 1976.

Jarvella, R. J., \& Collas, J. G. Memory for the intentions of sentences. Memory \& Cognition, 1974, 2, 185-188.

KEMPER, S. Memory for the form and force of declaratives and interrogatives. Memory \& Cognition, 1980, 8, 367-371.

RUmelharT, D. E. Understanding and summarizing stories. In D. LaBerge \& J. Samuels (Eds.), Basic processes in reading: Perception and comprehension. Hillsdale, N.J: Erlbaum, 1977.

Sнан, I. The exploits of the incomparable Mulla Nasrudin. New York: Dutton, 1972.

\section{NOTE}

1. An additional experiment, not reported here, examined the effects of discourse force on passage reading time, a dependent variable presumably tapping ongoing comprehension. There were no consistent effects of discourse force for any of the individual passages. One explanation for these results may be a lack of experimental control. The passages were vastly different in length, and a stopwatch was used for timing reading. Future research might benefit from the use of the more homogeneous passages and computer-driven equipment to collect more precise latencies. 